\title{
A Rapid and Green Procedure for the Synthesis of 5- Arylidene Rhodanine Derivatives
}

\author{
Liangliang Han and Zhongqiang Zhou* \\ College of Chemistry and Materials Science, South-Central University for Nationalities, Wuhan 430074, P. R. \\ China \\ Email: zhou-zq@hotmail.com
}

\begin{abstract}
A simple and efficient synthesis of 5-arylidene rhodanine derivatives by the Knoevenagel condensation of aromatic aldehydes with rhodanine in the presence of 2-hydroxy ethylammonium acetate under solvent-free conditions is described. The attractive features of this procedure are high yields, short reaction time, operational simplicity, mild and environmentally benign reaction conditions, easy preparation and reusability of the catalyst.
\end{abstract}

Keywords: 5-arylidene rhodanine derivatives; Knoevenagel condensation; solvent-free conditions; 2hydroxy ethylammonium acetate

\section{Introduction}

Rhodanine derivatives have shown a wide range of pharmacological activities, which include anticonvulsant, antibacterial, antiviral, and antidiabetic effects [1-3]. The preparation of 5-arylidene rhodanine derivatives can be carried out by condensation of aromatic aldehydes and rhodanine in the presence of various catalysts such as glycine [4], ammonium acetate [5-6], 2,2,6,6-tetramethyl piperidine [7-8], $\mathrm{NaOAc} / \mathrm{HOAc}$ [2,9-10], 1-butyl-3-methyl imidazolium hydroxide [11-12], $\mathrm{NH}_{4} \mathrm{Cl} / \mathrm{NH}_{4} \mathrm{OH}$ [13], ethylenediammonium diacetate [14], $\mathrm{K}_{2} \mathrm{CO}_{3} /[\mathrm{bmim}] \mathrm{BF}_{4} / \mathrm{H}_{2} \mathrm{O}$ [15], piperidine $[1,16-17]$, piperidine/AcOH [18-20]. Unfortunately, many of these methods suffer from one or other limitations such as low product yields, tedious work-up procedures, relatively long reaction time, use of organic solvent, use of special apparatus, use of expensive catalyst and difficulty in recovery and reusability of the catalyst. Thus, the development of an efficient and versatile method for the preparation of rhodanine derivatives is an active ongoing research area, and there is a potential for further improvement toward green chemistry and improved yields.

Organic reactions under solvent-free conditions have attracted much interest from chemists particularly from the viewpoint of green chemistry [21]. To the best of our knowledge, the activity of 2hydroxy ethylammonium acetate for synthesis of 5-arylidene rhodanine derivatives has not been studied. Herein we report a rapid and green synthesis of 5-arylidene rhodanine derivatives via a condensation of aromatic aldehydes and rhodanine under solvent-free conditions using 2-hydroxy ethylammonium acetate as an efficient and recyclable catalyst (Scheme 1).

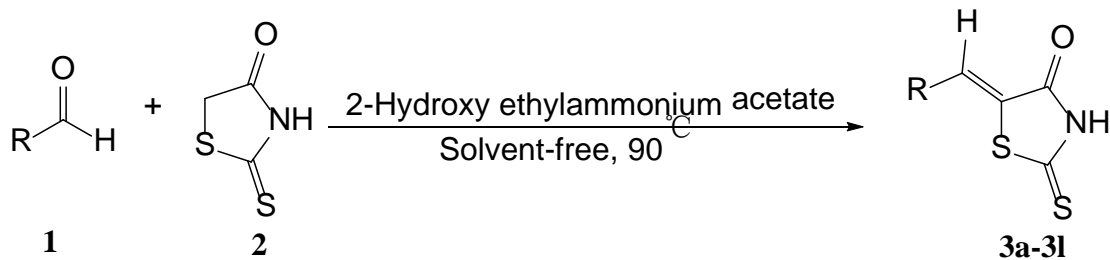

Scheme 1. Synthesis of 5-arylidene rhodanine derivatives 


\section{$2 \quad$ Experimental}

\section{$2.1 \quad$ General}

All chemicals were commercial products. Melting points were determined on an X-4 micro melting point apparatus and were uncorrected. FT-IR spectra were obtained as KBr pellets on a Nexus 470 spectrophotometer. ${ }^{1} \mathrm{H}$ NMR spectra were recorded in deuterated dimethylsulfoxide on a Bruker Avance III 400 with TMS as internal standard.

\subsection{Preparation of 2-hydroxyethylammonium Acetate}

To aminoethanol (12.2 g, $0.2 \mathrm{~mol})$ in a three-necked flask equipped with a reflux condenser and an addition funnel, acetic acid (12.0 g, $0.2 \mathrm{~mol})$ was added dropwise with stirring. Stirring was continued for $24 \mathrm{~h}$ at room temperature, to give a yellowish viscous clear liquid $(24.2 \mathrm{~g}, 100 \%)$. ${ }^{1} \mathrm{H}$ NMR (DMSO$\left.d_{6}, 400 \mathrm{MHz}\right): \delta 1.72\left(\mathrm{~s}, 3 \mathrm{H}, \mathrm{CH}_{3}-\mathrm{COO}^{-}\right), 2.71\left(\mathrm{t}, 2 \mathrm{H},-\mathrm{O}-\mathrm{CH}_{2}-\right), 3.48\left(\mathrm{t}, 2 \mathrm{H},-\mathrm{CH}_{2}-\mathrm{N}\right), 6.55$ (broad signal, $\left.4 \mathrm{H},-\mathrm{NH}_{3}+\mathrm{OH}\right)$.

\subsection{General Procedure for the Synthesis of 5-arylidene Rhodanine Derivatives}

A mixture of rhodanine $(0.665 \mathrm{~g}, 5 \mathrm{mmol})$, the aldehyde $(5 \mathrm{mmol})$, and 2-hydroxyethylammonium acetate $(0.061 \mathrm{~g}, 0.5 \mathrm{mmol})$ in a round bottom flask was stirred at $90{ }^{\circ} \mathrm{C}$ under neat conditions. The progress of the reaction was monitored by TLC (silica gel, using ethyl acetate-petroleum ether (1:1) as solvent). After completion of reaction, the reaction mixture was cooled to room temperature, whereupon it solidified. The solid mixture was recrystallized from ethanol to afford 5-arylidene rhodanine. All of the products are known, and physical data were found to be identical with those reported in the literature. The filtrate containing catalyst was subject to vacuum to remove solvent and the resulting catalyst was reused in four subsequent reactions without further purification.

\section{$3 \quad$ Results and Discussion}

2-Hydroxy ethylammonium acetate was easily prepared from cheaply available acetic acid and ethanolamine by a simple acid-base neutralization reaction [22]. In order to achieve optimum conditions, we initially investigated the reaction of 2,4-dichlorobenzaldehyde $(5 \mathrm{mmol})$ and rhodanine $(5 \mathrm{mmol})$ at different reaction temperatures $\left(70,80,90\right.$ and $\left.100{ }^{\circ} \mathrm{C}\right)$ in the presence of different amount of 2-hydroxy ethylammonium acetate $(5 \% \mathrm{~mol}, 10 \% \mathrm{~mol}, 15 \% \mathrm{~mol})$. The best result was obtained by carrying out the reaction with $10 \% \mathrm{~mol}$ of 2 -hydroxy ethylammonium acetate at $90{ }^{\circ} \mathrm{C}$ under solvent-free conditions (Table 1).

Table 1. Effect of different reaction conditions on synthesis of 5-arylidene rhodanine ${ }^{\text {a }}$.

\begin{tabular}{lllll}
\hline Entry & Catalyst $(\mathbf{m o l} \%)$ & Temperature $\left({ }^{\circ} \mathbf{C}\right)$ & Time $(\mathbf{m i n})$ & Yield $^{\text {b }}(\%)$ \\
\hline 1 & 10 & 70 & 60 & 62 \\
2 & 10 & 80 & 14 & 81 \\
3 & 10 & 90 & 11 & 84 \\
4 & 10 & 100 & 11 & 84 \\
5 & 5 & 90 & 11 & 67 \\
6 & 15 & 90 & 11 & 83 \\
\hline
\end{tabular}

a Reaction condition: 2,4-Dichlorobenzaldehyde $(5 \mathrm{mmol})$, rhodanine $(5 \mathrm{mmol})$, in the presence of 2-hydroxy ethylammonium acetate under solvent-free conditions.

${ }^{\mathrm{b}}$ Isolated yield.

With this optimized procedure in hand, the generality of this reaction was examined using different aldehydes. As seen from Table 2, aromatic aldehydes having electron-donating as well as electron- 
withdrawing groups were uniformly transformed into the corresponding 5-arylidene rhodanines in high to excellent yields within 2-11 min. Substituents on the aromatic ring had no obvious effect on yield or reaction time under the above optimal conditions. Arylmethylidenerhodanines can form two isomers. However, all arylmethylidenerhodanines reported in the present paper were obtained as single (Z)isomers $[3,13]$.

Table 2. 2-Hydroxy ethylammonium acetate catalyzed synthesis of 5-arylidene rhodanine derivatives ${ }^{\text {a }}$.

\begin{tabular}{llllll}
\hline \multirow{2}{*}{ Product } & \multirow{2}{*}{} & Time (min) & Yield $^{\mathbf{b}}(\boldsymbol{\%})$ & \multicolumn{2}{c}{ Mp $\left({ }^{\circ} \mathbf{C}\right)$} \\
\cline { 5 - 6 } & & & & Found & Reported \\
\hline $\mathbf{3 a}$ & $\mathrm{C}_{6} \mathrm{H}_{5}$ & 2 & 94 & $204-206$ & $205-207[15]$ \\
$\mathbf{3 b}$ & $4-\mathrm{CH}_{3} \mathrm{C}_{6} \mathrm{H}_{4}$ & 7 & 86 & $222-224$ & $221-223[15]$ \\
$\mathbf{3 c}$ & $4-\mathrm{CH}_{3} \mathrm{OC}_{6} \mathrm{H}_{4}$ & 8 & 91 & $248-250$ & $249-250[15]$ \\
$\mathbf{3 d}$ & $2-\mathrm{ClC}_{6} \mathrm{H}_{4}$ & 3 & 81 & $179-181$ & $181-182[15]$ \\
$\mathbf{3 e}$ & $4-\mathrm{FC}_{6} \mathrm{H}_{4}$ & 2 & 93 & $218-220$ & $219[3]$ \\
$\mathbf{3 f}$ & $4-\left(\mathrm{CH}_{3}\right)_{2} \mathrm{NC}_{6} \mathrm{H}_{4}$ & 3 & 91 & $269-271$ & $270-271[15]$ \\
$\mathbf{3 g}$ & $4-\mathrm{BrC}_{6} \mathrm{H}_{4}$ & 7 & 85 & $228-230$ & $230[3]$ \\
$\mathbf{3 h}$ & $3-\mathrm{NO}_{2} \mathrm{C}_{6} \mathrm{H}_{4}$ & 5 & 95 & $262-264$ & $263-265[15]$ \\
$\mathbf{3 i}$ & $4-\mathrm{ClC}_{6} \mathrm{H}_{4}$ & 6 & 88 & $227-229$ & $229-230[15]$ \\
$\mathbf{3 j}$ & $2,4-\mathrm{Cl}_{2} \mathrm{C}_{6} \mathrm{H}_{3}$ & 11 & 84 & $232-234$ & $233-234[15]$ \\
$\mathbf{3 k}$ & $2-\mathrm{HOC}_{6} \mathrm{H}_{4}$ & 10 & 82 & $222-224$ & $221-222[10]$ \\
$\mathbf{3 l}$ & $2-\mathrm{Furyl}$ & 6 & 87 & $227-229$ & $228-229[15]$ \\
\hline
\end{tabular}

${ }^{\text {a }}$ Reaction condition: aldehyde $(5 \mathrm{mmol})$, rhodanine $(5 \mathrm{mmol})$, 2-hydroxy ethylammonium acetate $(0.5 \mathrm{mmol})$ at $90{ }^{\circ} \mathrm{C}$ under solvent-free conditions.

${ }^{\mathrm{b}}$ Isolated yield.

The reusability of the catalyst was examined in the synthesis of 5-benzylidene rhodanine. The results were summarized in Table 3 . When the reaction was completed, the reaction mixture was recrystallized from ethanol. The mother liquor was evaporated to dryness and the resulting catalyst was reused without any treatment [23]. It was found that the catalyst could be reused at least four times without significant loss of activity.

Table 3. Recycling of the 2-hydroxy ethylammonium acetate for the synthesis of 5-benzylidene rhodanine.

\begin{tabular}{lll}
\hline Run & Time (min) & Yield (\%) \\
\hline 1 & 2 & 94 \\
2 & 2 & 92 \\
3 & 2 & 90 \\
4 & 2 & 89 \\
5 & 3 & 87 \\
\hline
\end{tabular}

\section{Conclusion}

In summary, we have developed a rapid and environment-friendly method for the synthesis of 5arylidene rhodanine derivatives by the condensation reaction of rhodanine and aromatic aldehydes in the presence of 2-hydroxy ethylammonium acetate. The present method has many obvious advantages, including simplicity of the methodology, ease of product isolation, good yields, short reaction time, use of a very cheap and recyclable catalyst, and being environmentally benign. We believe this will provide a practical alternative to the existing methods for the synthesis of 5-arylidene rhodanine derivatives.

\section{References}

1. Y. Momose, K. Meguro, H. Ikeda, C. Hatanaka, S. Oi and T. Sohda, "Studies on antidiabetic agents. X. 
Synthesis and biological activities of pioglitazone and related compounds," Chemical \& Pharmaceutical Bulletin, vol. 39, no. 6, pp. 1440-1445, 1991.

2. J. H. Ahn, S. J. Kim, W. S. Park, S. Y. Cho, J. D. Ha, S. S. Kim, S. K. Kang, D. G. Jeong, S.-K. Jung, S.-H. Lee, H. M. Kim, S. K. Park, K. H. Lee, C. W. Lee, S. E. Ryub and J.-K. Choi, "Synthesis and biological evaluation of rhodanine derivatives as PRL-3 inhibitors," Bioorganic \& Medicinal Chemistry Letters, vol. 16, no. 11, pp. 29962999, 2006 .

3. M. Sortino, P. Delgado, S. Juarez, J. Quiroga, R. Abonıa, B. Insuasty, M. Nogueras, L. Rodero, F. M. Garibotto, R. D. Enrize and S. A. Zacchinoa, "Synthesis and antifungal activity of (Z)-5-arylidenerhodanines," Bioorganic \& Medicinal Chemistry, vol. 15, no. 1, pp. 484-494, 2007.

4. B. Y. Yang and D. H. Yang, "Solvent-free synthesis of 5-benzylidene-2-thioxothiazolidin-4-ones and thiazolidine2,4-diones catalysed by glycine under microwave irradiation," Journal of Chemical Research, vol. 35, no. 4, pp. 238-239, 2011.

5. N. H. Metwally, N. M. Rateb and H. F. Zohdi, "A simple and green procedure for the synthesis of 5-arylidene-4thiazolidinones by grinding," Green Chemistry Letters and Reviews, vol. 4, no. 3, pp. 225-228, 2011.

6. D. Hardej, C. R. Ashby, N. S. Khadtare, S. S. Kulkarni, S. Singh and T. T. Talele, "The synthesis of phenylalanine-derived $\mathrm{C} 5$-substituted rhodanines and their activity against selected methicillin-resistant Staphylococcus aureus (MRSA) strains," European Journal of Medicinal Chemistry, vol. 45, no. 12, pp. 58275832,2010 .

7. S. Kamila, H. Ankati and E. R. Biehl, An efficient microwave assisted synthesis of novel class of Rhodanine derivatives as potential HIV-1 and JSP-1 inhibitors. Tetrahedron Letters, vol. 52, no. 34, pp. 4375-4377, 2011.

8. S. Kamila and E. R. Biehl, "Microwave-assisted synthesis of novel bis(2-thioxothiazolidin-4-one) derivatives as potential GSK-3 inhibitors," Tetrahedron Letters, vol. 53, no. 31, pp. 3998-4003, 2012.

9. H. Li, J. Yang, S. Ma and C. Qiao, "Structure-based design of rhodanine-based acylsulfonamide derivatives as antagonists of the anti-apoptotic Bcl-2 protein," Bioorganic \& Medicinal Chemistry, vol. 20, no. 14, pp. 41944200, 2012.

10. J. Zhou, Y. Song, F. Zhu and Y. Zhu, "Facile synthesis of 5-benzylidene rhodamine derivatives under microwave irradiation," Synthetic Communications, vol. 36, no. 22, pp. 3297-3303, 2006.

11. K. Gong, Z. He, Y. Xu, D. Fang and Z. Liu, "Green synthesis of 5-benzylidene rhodanine derivatives catalyzed by 1-butyl-3-methyl imidazolium hydroxide in water," Monatshefte Fuer Chemie, vol. 139, no. 8, pp. 913-915, 2008.

12. J. J. Ma, S. T. Gao, Z. Li, R. X. Tang, H. Y. Liu, C. Wang and Y. Gao, "Synthesis of 5-arylmethylidene-2-thio4-thiazolidinone derivatives catalyzed by alkaline ionic liquid," Chinese Journal of Organic Chemistry, vol. 28, no. 2, pp. 339-342, 2008.

13. V. Opletalova, J. Dolezel, K. Kralova, M. Pesko, J. Kunes and J. Jampilek, "Synthesis and characterization of (Z)-5-arylmethylidenerhodanines with photosynthesis-inhibiting properties," Molecules, vol. 16, no. 16, pp. 5207$5227,2011$.

14. W. Hanefeld and M. Schlitzer, "Synthesis of 3-aminorhodanine derivatives as aldose reductase inhibitors," Journal of Heterocyclic Chemistry, vol. 32, no. 3, pp. 1019-1025, 1995.

15. X. Z. Lian, Y. Q. Li, and M. Y. Zhou, "Ionic liquid/H2O system promoted condensation of aromatic aldehydes and rhodamine," Chinese Journal of Organic Chemistry, vol. 26, no. 9, pp. 1272-1274, 2006.

16. O. Zvarec, S. W. Polyak, W. Tieu, K. Kuan, H. Dai, D. S. Pedersen, R. Morona, L. Zhang, G. W. Booker and A. D. Abell, "5-Benzylidenerhodanine and 5-benzylidene-2-4-thiazolidinedione based antibacterials," Bioorganic \& Medicinal Chemistry Letters, vol. 22, no. 8, pp. 2720-2722, 2012.

17. M. J. Robertson, G. Hadzic, J. Ambrus, D. Y. Pome, E. Hyde, A. Whiting, A. Mariana, L. Kleist, N. Chau, V. Haucke, P. J. Robinson and A. McCluskey, "The rhodadyns, a new class of small molecule inhibitors of Dynamin GTPase activity," ACS Medicinal Chemistry Letters, vol. 3, no. 5, pp. 352-356, 2012.

18. N. Zidar, T. Tomasic, R. Sink, V. Rupnik, A. Kovac, S. Turk, D. Patin, D. Blanot, C. C. Martel, A. Dessen, M. M. Premru, A. Zega, S. Gobec, L. P. Masic and D. Kikelj, "Discovery of novel 5-benzylidenerhodanine and 5benzylidenethiazolidine-2,4-dione inhibitors of MurD ligase," Journal of Medicinal Chemistry, vol. 53, no. 18, pp. 6584-6594, 2010.

19. N. Zidara, T. Tomasic, R. Sink, A. Kovac, D. Patin, D. Blanot, C. Contreras-Martel, A. Dessen, M. M. Premru, A. Zega, S. Gobec, L. P. Masic and D. Kikelj, "New 5-benzylidenethiazolidin-4-one inhibitors of bacterial MurD 
ligase: Design, synthesis, crystal structures, and biological evaluation," European Journal of Medicinal Chemistry, vol. 46, no. 11, pp. 5512-5523, 2011.

20. M. Song, C. Zheng, X. Deng, Q. Wang, S. Hou, T. Liu, X. Xing and H. Piao, "Synthesis and bioactivity evaluation of rhodanine derivatives as potential anti-bacterial agents," European Journal of Medicinal Chemistry, vol. 54, no. 11, pp. 403-412, 2012.

21. K. Tanaka and F. Toda, "Solvent-free organic synthesis," Chemical Reviews, vol. 100, no. 3, pp. 1025-1074, 2000 .

22. I. Cota, R. Gonzalez-Olmos, M. Iglesias and F. Medina, "New short aliphatic chain ionic liquids: synthesis, physical properties, and catalytic activity in aldol condensations," Journal of Physical Chemistry B, vol. 111, no. 43, pp. 12468-12477, 2007.

23. S. Kantevari, M. V. Chary, A. P. R. Das, S. V. N. Vuppalapati and N. Lingaiah, "Catalysis by an ionic liquid: highly efficient solvent-free synthesis of aryl-14H-dibenzo[a.j]xanthenes by molten tetrabutylammonium bromide under conventional and microwave heating," Catalysis Communications, vol. 9, no. 7, pp. 1575-1578, 2008. 